Journal of Organometallic Chemistry, 418 (1991) 127-145

Elsevier Sequoia S.A., Lausanne

JOM 22030

\title{
Alkali metal derivatives of sulfinimidamides. Preparation and crystal structures
}

\author{
Frank Pauer and Dietmar Stalke * \\ Institut für Anorganische Chemie der Universität, Tammannstraße 4, W-3400 Göttingen (Germany) \\ (Received March 19th, 1991)
}

\begin{abstract}
A series of compounds has been prepared in which the $\mathrm{NH}$ proton of the sulfiniminamines $\mathrm{Me}_{3} \mathrm{SiN}=\mathrm{S}(\mathrm{R})-\mathrm{NHR}^{\prime}\left(\mathrm{R}=\mathrm{Ph}\right.$ (mainly) or ' $\mathrm{Bu}, \mathrm{R}^{\prime}={ }^{\prime} \mathrm{Bu}$ or $\mathrm{SiMe}_{3}$ ) is replaced by $\mathrm{Li}, \mathrm{Na}, \mathrm{K}, \mathrm{Rb}$, or Cs. The compounds form a series of reagents of increasing reactivity which could be used, for example, to introduce chelating ligands into transition metal complexes. The structures of the compounds have been determined by X-ray diffraction. When there is a phenyl substituent on the sulfur atom, the metal derivatives are isomorphic dimers, involving three fused four-membered rings in a step-shaped structure. The higher the atomic number of the metal, the stronger is the $\eta$-coordination of the phenyl group to the metal. With a t-butyl group on the sulfur atom the structures of the lithium derivatives $\left[\left(\mathrm{Me}_{3} \mathrm{SiN}=\right.\right.$ $\left.\left.\mathbf{S}\left({ }^{\prime} \mathrm{Bu}\right)-\mathrm{NR}^{\prime}\right) \mathrm{Li}\right]_{2}$ are different for $\mathbf{R}^{\prime}=\mathrm{SiMe}_{3}$ and 'Bu. For the former the step-shaped structure is still present, but the latter forms an eight-membered ring. Although these ${ }^{2} \mathrm{Bu}$ derivatives are synthesized in diethyl ether, their lithium atoms are not coordinated by donor molecules, in contrast to those in the phenyl-substituted species.
\end{abstract}

\section{Introduction}

The first sulphur diimide $\mathrm{S}\left(\mathrm{NSiMe}_{3}\right)_{2}$ was obtained by Wannagat und Kuchertz [1] in 1962, reacting a bis(trimethylsilyl)substituted alkali metal amide with $\mathrm{SCl}_{2}$. Scherer and Schmitt described a synthesis of $N, N, N^{\prime}$-tris(trimethylsilyl)(methyl) sulfiniminamine in 1969; they treated methyllithium with sulphurdiimide then added trimethylchlorosilane, to obtain $\mathrm{Me}_{3} \mathrm{SiN}=\mathrm{S}(\mathrm{Me}) \mathrm{N}\left(\mathrm{SiMe}_{3}\right)_{2}$ [2]. The reactivity and structure of lithiumorganylsulfinimidamides were first discussed in 1976 [3]. Lithium derivatives are accessible via metal exchange reactions, and sulfinimidamide anions are of interest as ligands in transition metal chemistry [4]. By variation of the substituents on nitrogen, anions of various bulks can be made [5].

Our aim is to prepare (and structurally characterize) "tailor-made" alkali metal organylsulfinimidamides in order to enable reaction with even less reactive transition metal halides.

\section{Results and discussion}

The sulphur diimides $\mathrm{Me}_{3} \mathrm{SiN}=\mathrm{S}=\mathrm{NR}$ react with phenyllithium in diethylether at $-60^{\circ} \mathrm{C}$. The products $1 \mathrm{a}$ and $1 \mathrm{~b}$ are dimers, containing only one coordinated ether 


$$
\begin{aligned}
& 2 \mathrm{Me}_{3} \mathrm{Si}-\mathrm{N}=\mathrm{S}=\mathrm{N}-\mathrm{R}+2 \mathrm{PhLi} \stackrel{\mathrm{Et}_{2} \mathrm{O}}{\longrightarrow}\left[\mathrm{Me}_{3} \mathrm{Si}-\mathrm{N} \mathrm{Li}_{2}^{\mathrm{Ph}}-\mathrm{R}\right]_{2} \cdot \mathrm{Et}_{2} \mathrm{O} \\
& \left(\mathrm{R}={ }^{\mathrm{t}} \mathrm{Bu}, \mathbf{1 a} ; \mathrm{SiMe}_{3}, \mathbf{1 b}\right)
\end{aligned}
$$

$\mathbf{1 a}, \mathbf{1 b}+\mathrm{H}_{2} \mathrm{O} \underset{-2 \mathrm{LiOH}}{\stackrel{2}{\longrightarrow}} 2 \mathrm{Me}_{3} \mathrm{Si}-\mathrm{N}=\mathrm{S}-\left.\right|_{\mathrm{H}} ^{\mathrm{Ph}}-\mathrm{R}$

$$
\left(\mathrm{R}={ }^{\mathrm{l}} \mathrm{Bu}, \mathbf{2 a} ; \mathrm{SiMe}_{3}, \mathbf{2 b}\right)
$$

Scheme 1

molecule according to NMR-spectroscopic investigations. In addition, the lithium atoms appear to be in magnetically different environments [9].

After hydrolysis [7] the phenylsulfiniminamines $\mathbf{2 a}$ and $\mathbf{2 b}$ can be obtained as white crystalline solids in moderate yields.

To make the sodium and potassium derivatives, the $N$-trimethylsilyl- $N^{\prime}$-tertbutyl-S-phenylsulfiniminamine $2 \mathrm{a}$ was treated with sodium or potassium hydride. The products 3 and 4 are dimers which are coordinated by one THF molecule per monomer. Treatment of the $N, N^{\prime}$-bis(trimethylsilyl)-S-phenylsulfiniminamine (2b) with rubidium and caesium gives the corresponding alkali metal derivatives 5 and 6 .

The rubidium and caesium $N, N^{\prime}$-bis(trimethylsilyl)-S-phenylsulfinimidamides 5 and 6 are also dimers with one THF molecule per monomer. A different structural type was obtained by the reaction of a sulphur diimide with tert-butyl lithium.

$2 \mathrm{a}+\mathrm{MH} \underset{-\mathrm{H}_{2}}{\stackrel{\mathrm{THF}}{\longrightarrow}} \frac{1}{2}\left[\mathrm{Me}_{3} \mathrm{Si}\right.$

$$
(\mathrm{M}=\mathrm{Na}, 3 ; \mathrm{K}, 4)
$$

$2 b+M \frac{\mathrm{THF}_{-\frac{1}{2} \mathrm{H}_{2}}}{\stackrel{\mathrm{THF}}{2}} \frac{1}{\mathrm{Me} \mathrm{Si}-\mathrm{SiMe}_{3}}$

$$
(\mathrm{M}=\mathrm{Rb}, 5 ; \mathrm{Cs}, 6)
$$




$$
2 \mathrm{Me}_{3} \mathrm{Si}-\mathrm{N}=\mathrm{S}=\mathrm{N}-\mathrm{R}+2{ }^{\mathrm{t}} \mathrm{BuLi} \stackrel{\mathrm{Et}_{2} \mathrm{O}}{\longrightarrow}\left[\begin{array}{c}
\mathrm{Me}_{3} \mathrm{Si}-\mathrm{N} \\
\mathrm{Li}
\end{array}\right]_{2}^{\mathrm{L}}
$$

Scheme 3

Although the reaction was carried out in diethyl ether, like the preparation of $1 \mathbf{a}$ and $\mathbf{1 b}$, no coordinated ether was present in the product.

\section{Crystal structure of $2 a$}

The $N$-trimethylsilyl- $N^{\prime}$-tert-butyl-S-phenylsulfiniminamine (2a) is a monomer in the solid state (Fig. 1). Table 1 presents the crystallographic data, Table 2 selected bond lengths and angles, and Table 3 the fractional coordinates.

The two sulphur-nitrogen bonds differ by $9.7 \mathrm{pm}$. The N2 nitrogen atom makes a single bond to the sulphur atom and is additionally bonded to a tert-butyl group and a hydrogen atom, the position of which was determined from a difference-Fourier-synthesis. The N2 atom clearly shows a pyramidal environment, and is $31.5 \mathrm{pm}$ above the plane defined by the neighbouring atoms. The distance of $157.0(1) \mathrm{pm}$ between $\mathrm{S} 1$ and $\mathrm{N} 1$ does not quite correspond to the length of a double bond.

The value of the torsion angle $\mathrm{N} 1-\mathrm{S} 1-\mathrm{C} 1-\mathrm{C} 6\left(31.5^{\circ}\right)$ shows that the plane of the phenyl ring is almost perpendicular to the bisector of the plane defined by the sulphur and the nitrogen atoms. The angle $\mathrm{N} 1-\mathrm{S} 1-\mathrm{Cl}$ is $7.7^{\circ}$ greater than the angle $\mathrm{N} 2-\mathrm{S} 1-\mathrm{C} 1$, i.e. the nitrogen atom with the shorter bond to the sulphur atom defines the greater $\mathrm{N}-\mathrm{S}-\mathrm{C}$ angle of the two.

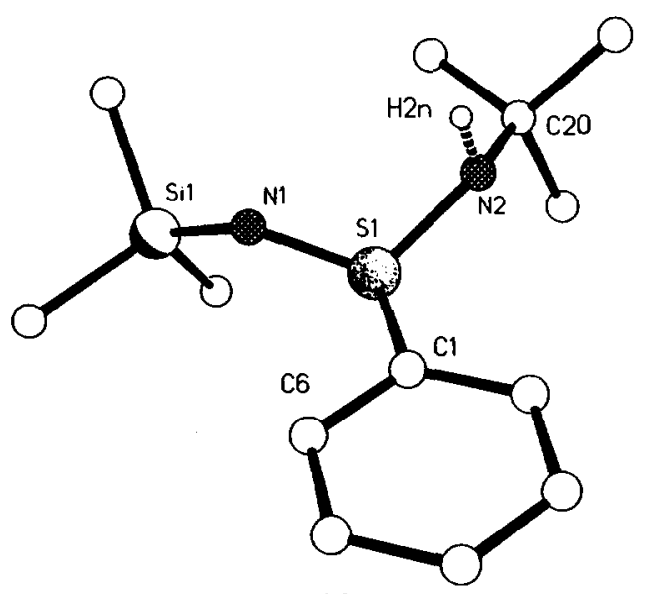

Fig. 1. Crystal structure of $\mathbf{2 a .}$ 


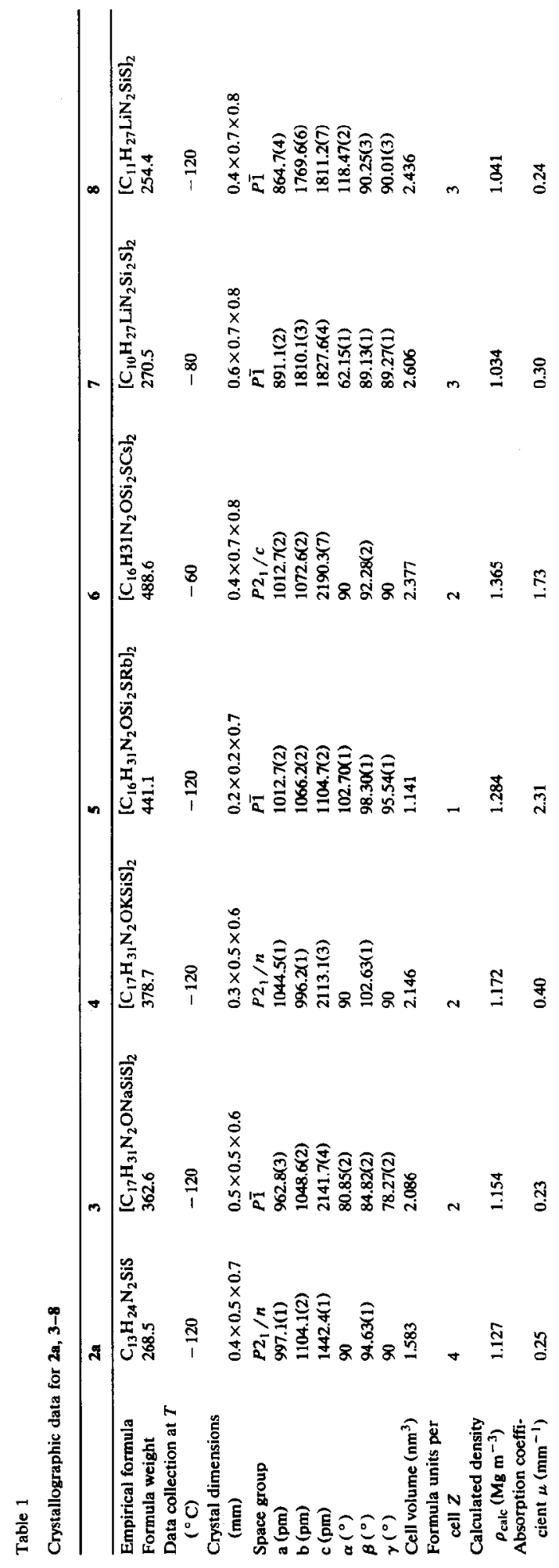




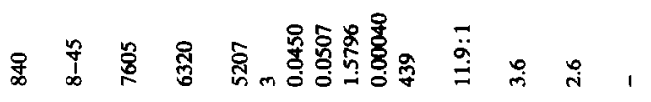

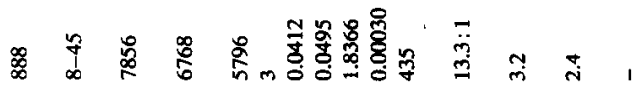

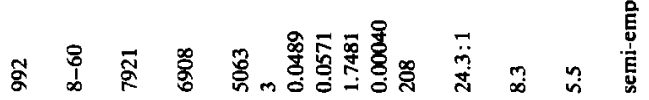

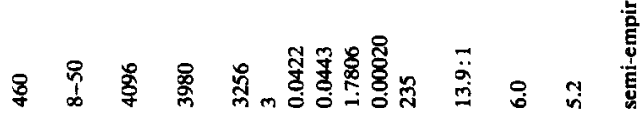

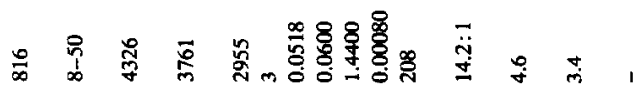

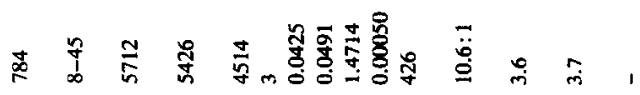

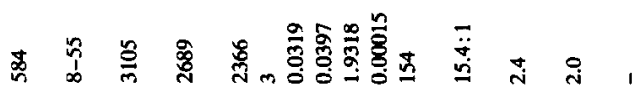




Table 2

Selected bond lengths $(\mathrm{pm})$ and angles $\left({ }^{\circ}\right)$ for $2 \mathrm{a}, 3-6$

\begin{tabular}{|c|c|c|c|c|c|}
\hline & $2 a$ & $3^{a}$ & 4 & 5 & 6 \\
\hline M1 & - & $\mathbf{N a}$ & $\mathbf{K}$ & $\mathbf{R b}$ & Cs \\
\hline $\mathbf{R}$ & 'Bu & ${ }^{\mathrm{t}} \mathrm{Bu}$ & ${ }^{t} \mathrm{Bu}$ & $\mathrm{SiMe}_{3}$ & $\mathrm{SiMe}_{3}$ \\
\hline M1-N1 & - & $239.9(3)$ & $275.2(3)$ & $287.7(4)$ & $304.5(3)$ \\
\hline M1-N2 & - & $263.2(3)$ & $288.0(2)$ & $308.3(3)$ & $325.0(3)$ \\
\hline M1-N2a & - & $240.9(3)$ & $283.4(3)$ & $292.2(2)$ & $318.7(3)$ \\
\hline M1-O1 & - & $235.0(2)$ & $271.6(3)$ & $291.6(3)$ & $310.1(5)$ \\
\hline S1-N1 & $157.0(1)$ & $160.7(3)$ & $160.1(3)$ & $158.9(4)$ & $158.7(3)$ \\
\hline S1-N2 & $166.7(1)$ & $162.3(3)$ & $161.7(3)$ & $161.5(3)$ & $160.9(3)$ \\
\hline S1-C1 & $179.9(2)$ & $181.0(3)$ & $180.5(3)$ & $180.7(3)$ & $180.9(4)$ \\
\hline M1-cent. & - & 386.3 & 369.8 & 369.9 & 355.1 \\
\hline $\mathrm{N} 1-\mathrm{S} 1-\mathrm{N} 2$ & $113.5(1)$ & $110.7(1)$ & $110.4(1)$ & $110.4(2)$ & $108.3(2)$ \\
\hline $\mathrm{N} 1-\mathrm{S} 1-\mathrm{C} 1$ & $105.0(1)$ & $103.1(1)$ & $103.5(1)$ & $102.7(2)$ & 103.3(2) \\
\hline $\mathrm{N} 2-\mathrm{S} 1-\mathrm{Cl}$ & $97.3(1)$ & $98.5(1)$ & $99.3(1)$ & $99.4(1)$ & $99.7(2)$ \\
\hline $\mathrm{C} 1-\mathrm{P}_{\mathrm{NSN}}^{b}$ & 111.2 & 109.4 & 110.4 & 109.7 & 110.0 \\
\hline $\mathbf{M}-\mathbf{P h}-\mathbf{P}_{\mathrm{Ph}}$ c & - & 49.1 & 57.7 & 61.0 & 77.6 \\
\hline $\mathrm{P}_{\mathrm{NSNM}}-\mathrm{P}_{\mathrm{NMNM}}{ }^{d}$ & - & 133.3 & 123.9 & 122.6 & 115.1 \\
\hline $\mathrm{N} 1-\mathrm{S} 1-\mathrm{Cl}-\mathrm{C} 6$ & 31.5 & 16.2 & 11.2 & 6.3 & -8.6 \\
\hline
\end{tabular}

average values of two independent molecules; esd's reflect the extreme values. ${ }^{b}$ Angle of the S1-C1 vectors to the plane defined by N1-S1-N2. 'Angle of the vectors M1-phenyl centre to the plane of the phenyl ring. ${ }^{d}$ Angle between the four-membered ring units M1-N2-S1-N2 and M1-N2-M1a-N2a.

Crystal structures of the alkali metal derivatives $3(\mathrm{Na}), 4(\mathrm{~K}), 5(\mathrm{Rb})$, and $6(\mathrm{Cs})$

The structures are depicted in Figs. 2-5. Relevant crystallographic data are given in Table 1, selected bond lengths and angles in Table 2, and fractional coordinates in Tables 4-7.

Table 3

Atomic coordinates $\left(\times 10^{4}\right)$ and equivalent isotropic displacement coefficients $\left(\mathrm{pm}^{2} \times 10^{-1}\right)$ for $2 \mathrm{a}$

\begin{tabular}{lllll}
\hline & $x$ & $y$ & $z$ & $U_{\text {eq }}^{a}$ \\
\hline $\mathrm{S}(1)$ & $5493(1)$ & $3482(1)$ & $6138(1)$ & $24(1)$ \\
$\mathrm{N}(1)$ & $6283(1)$ & $4713(1)$ & $6175(1)$ & $26(1)$ \\
$\mathrm{C}(1)$ & $6295(2)$ & $2570(2)$ & $5309(1)$ & $23(1)$ \\
$\mathrm{C}(2)$ & $7658(2)$ & $2739(2)$ & $5235(1)$ & $29(1)$ \\
$\mathrm{C}(3)$ & $8338(2)$ & $1963(2)$ & $4678(1)$ & $36(1)$ \\
$\mathrm{C}(4)$ & $7669(2)$ & $1032(2)$ & $4204(1)$ & $36(1)$ \\
$\mathrm{C}(5)$ & $6310(2)$ & $870(2)$ & $4281(1)$ & $36(1)$ \\
$\mathrm{C}(6)$ & $5617(2)$ & $1632(2)$ & $4836(1)$ & $30(1)$ \\
$\mathrm{Si}(1)$ & $6849(1)$ & $5377(1)$ & $7214(1)$ & $28(1)$ \\
$\mathrm{C}(11)$ & $6108(2)$ & $6924(2)$ & $7250(1)$ & $45(1)$ \\
$\mathrm{C}(12)$ & $8720(2)$ & $5523(2)$ & $7263(1)$ & $39(1)$ \\
$\mathrm{C}(13)$ & $6411(2)$ & $4513(2)$ & $8264(1)$ & $42(1)$ \\
$\mathrm{N}(2)$ & $3983(1)$ & $3565(1)$ & $5555(1)$ & $26(1)$ \\
$\mathrm{C}(20)$ & $2793(2)$ & $3708(2)$ & $6115(1)$ & $31(1)$ \\
$\mathrm{C}(21)$ & $2829(2)$ & $4896(2)$ & $6655(1)$ & $37(1)$ \\
$\mathrm{C}(22)$ & $1579(2)$ & $3696(2)$ & $5405(2)$ & $50(1)$ \\
$\mathrm{C}(23)$ & $2749(2)$ & $2633(2)$ & $6777(2)$ & $49(1)$ \\
\hline
\end{tabular}

\footnotetext{
${ }^{a}$ Equivalent isotropic $U$ defined as one third of the trace of the orthogonalized $U_{i j}$ tensor.
} 

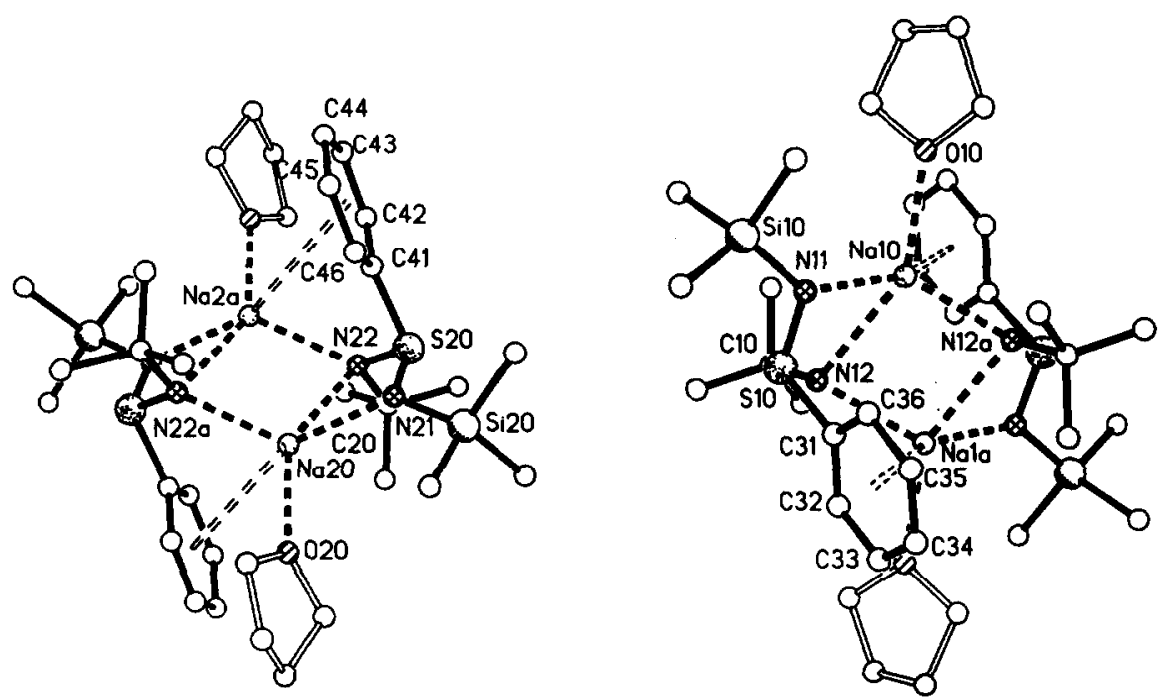

Fig. 2. Crystal structure of 3. In the Discussion the chemically-equivalent atoms $\mathbf{S 1 0}$ and $\mathbf{S 2 0}$ are referred to as $\mathrm{S} 1, \mathrm{~N} 11$ and N21 as N1, etc.

Like the alkali metal derivatives investigated by Veith et al. $[10,11]$ and sodium (ditert-butylfluorosilyl)tert-butylamide [12], the alkali metal sulfinimidamides described here have a step-shaped structure (Fig. 2). Unlike lithium(ditert-butylfluoro-

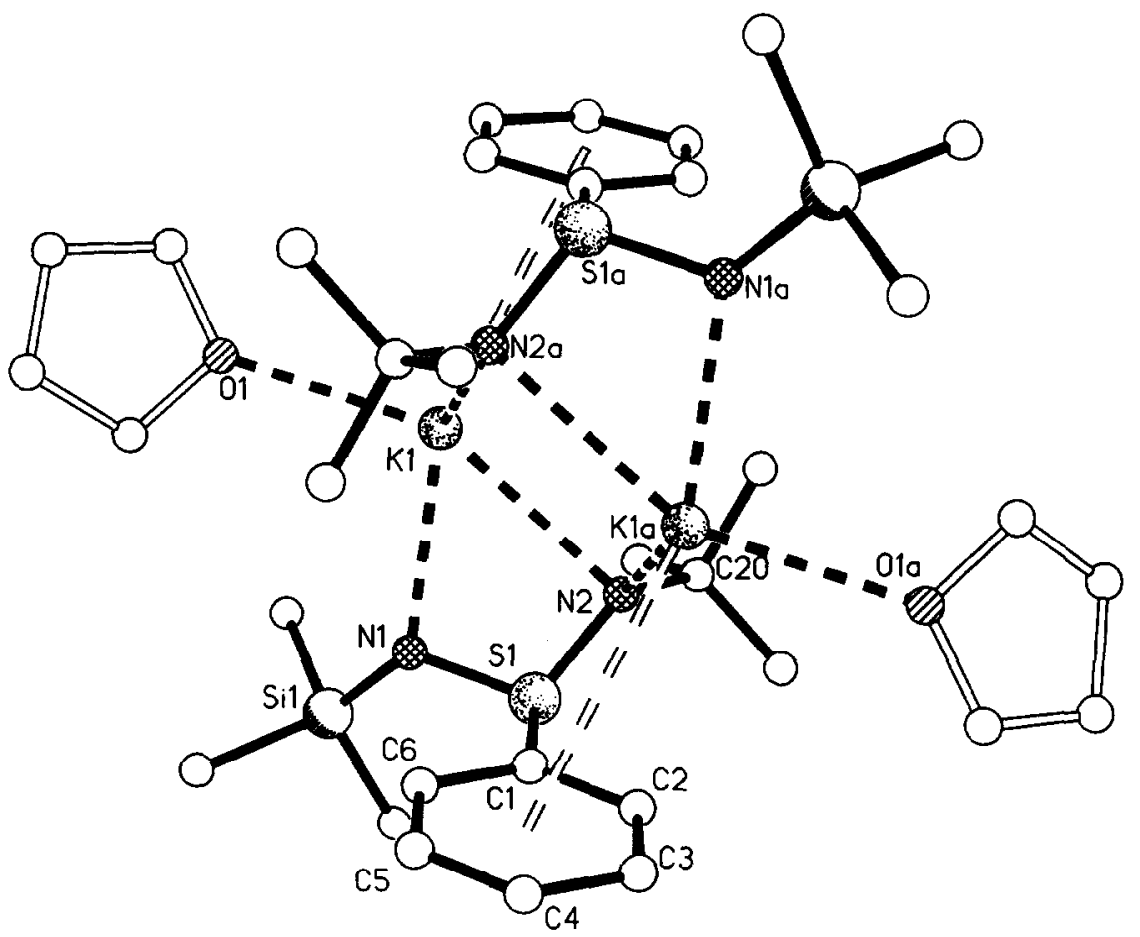

Fig. 3. Crystal structure of 4. 


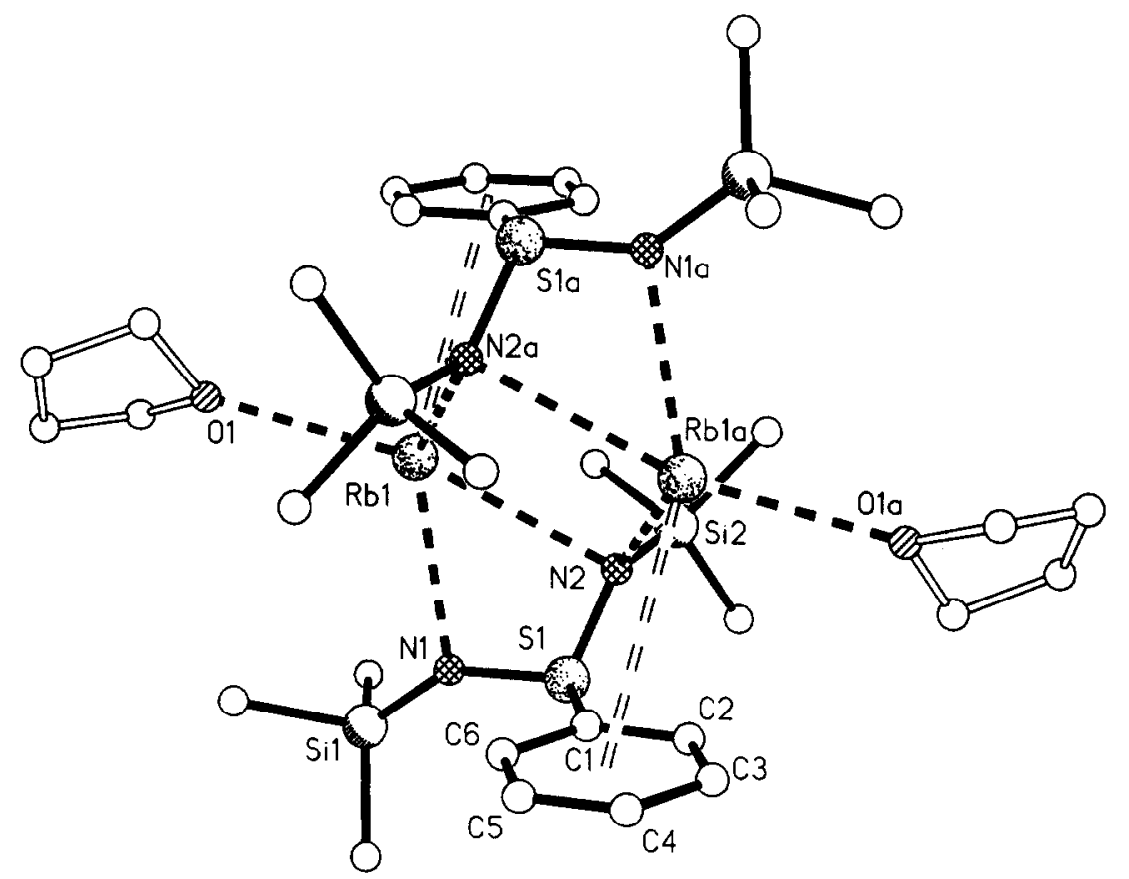

Fig. 4. Crystal structure of 5.

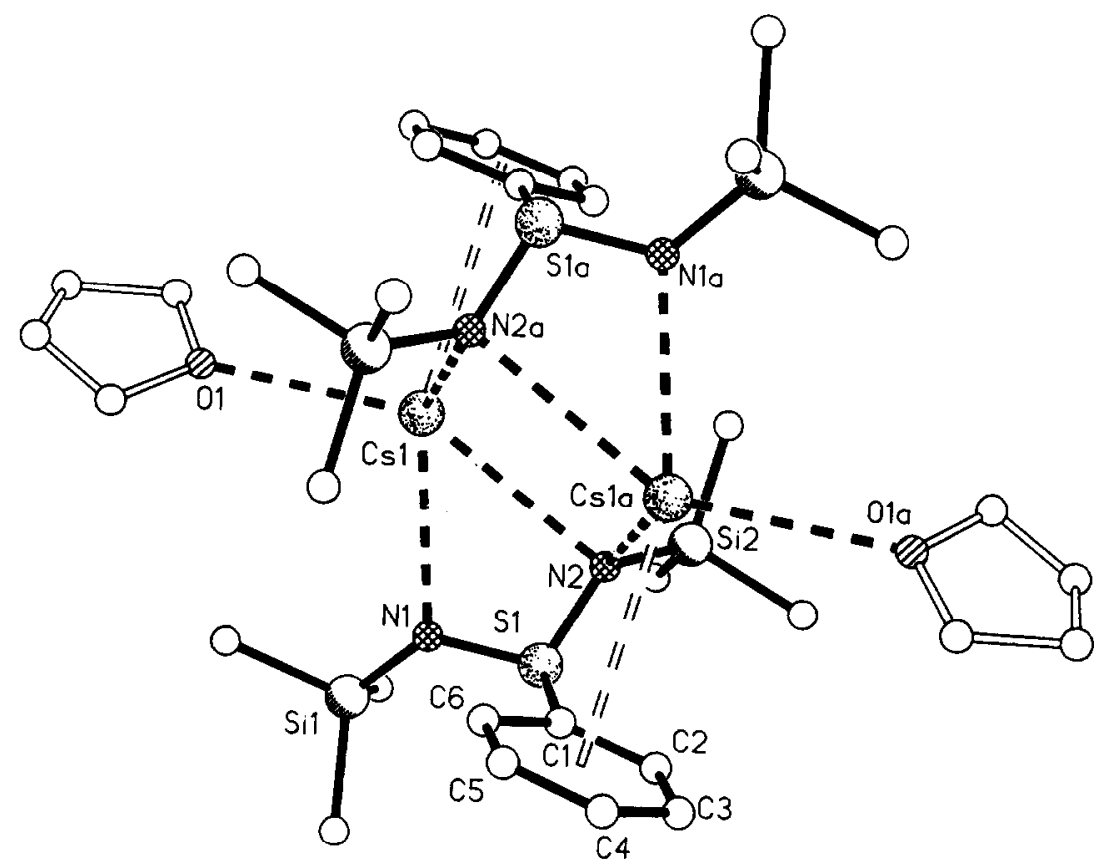

Fig. 5. Crystal structure of 6. 
Table 4

Atomic coordinates $\left(\times 10^{4}\right)$ and equivalent isotropic displacement coefficients $\left(\mathrm{pm}^{2} \times 10^{-1}\right)$ for 3

\begin{tabular}{|c|c|c|c|c|}
\hline & $x$ & $y$ & $z$ & $U_{\mathrm{eq}}{ }^{a}$ \\
\hline$S(10)$ & 4306(1) & $3713(1)$ & $9002(1)$ & $26(1)$ \\
\hline$C(31)$ & $3412(3)$ & $2887(3)$ & $9679(1)$ & $27(1)$ \\
\hline $\mathrm{C}(32)$ & $4138(3)$ & $1791(3)$ & $10050(1)$ & $33(1)$ \\
\hline$C(33)$ & $3429(3)$ & $1136(3)$ & $10549(1)$ & $39(1)$ \\
\hline$C(34)$ & 1997(3) & $1564(3)$ & $10681(1)$ & $42(1)$ \\
\hline$C(35)$ & $1266(3)$ & $2642(3)$ & $10309(1)$ & $39(1)$ \\
\hline$C(36)$ & 1968(3) & $3306(3)$ & 9803(1) & $33(1)$ \\
\hline $\mathrm{N}(11)$ & 3199(2) & $5071(2)$ & $8829(1)$ & $29(1)$ \\
\hline $\mathrm{Si}(10)$ & $2444(1)$ & $5403(1)$ & $8114(1)$ & $25(1)$ \\
\hline$C(11)$ & $3685(3)$ & $5855(3)$ & $7436(1)$ & $42(1)$ \\
\hline $\mathrm{C}(12)$ & $1750(3)$ & $3987(3)$ & $7909(2)$ & $45(1)$ \\
\hline $\mathrm{C}(13)$ & 934(3) & $6806(3)$ & $8168(2)$ & $41(1)$ \\
\hline $\mathrm{N}(12)$ & $5634(2)$ & 3953(2) & $9358(1)$ & $26(1)$ \\
\hline$C(10)$ & $6956(3)$ & $4027(3)$ & $8936(1)$ & $38(1)$ \\
\hline$C(14)$ & $8170(3)$ & $3736(3)$ & 9382(2) & $44(1)$ \\
\hline$C(15)$ & $6901(3)$ & $5420(3)$ & $8569(2)$ & $51(1)$ \\
\hline$C(16)$ & 7268(3) & $3020(4)$ & $8473(2)$ & $53(1)$ \\
\hline $\mathrm{Na}(10)$ & $4097(1)$ & $6275(1)$ & 9521(1) & $31(1)$ \\
\hline$O(10)$ & $3049(2)$ & $8439(2)$ & $9084(2)$ & $45(1)$ \\
\hline$C(51)$ & $1943\langle 4\rangle$ & $9411(3)$ & $9311(2)$ & $5 x<1\}$ \\
\hline$C(52)$ & $1632(4)$ & $10500\{4\}$ & $8765(2)$ & $71(2)$ \\
\hline$C(53)$ & $3068(6)$ & $10398(5)$ & $8380(3)$ & $64(2)$ \\
\hline$C\left(53^{\prime}\right)$ & $2360(22)$ & $10023(15)$ & $8209(7)$ & $77(11)$ \\
\hline$C(54)$ & 3584447 & 89437 & ¿A48(2) & faYY\}) \\
\hline$S(20)$ & $8976(1)$ & $1614(1)$ & $5975(1)$ & $28(1)$ \\
\hline$C(41)$ & $8132(3)$ & 2719(3) & $5320(1)$ & $28(1)$ \\
\hline$C(42)$ & $8836(3)$ & $3653(3)$ & 4973(1) & $35(1)$ \\
\hline$C(43)$ & $8148(4)$ & $4559(3)$ & $4501(2)$ & $46(1)$ \\
\hline$C(44)$ & $6774(4)$ & $4534(3)$ & $4376(2)$ & $51(1)$ \\
\hline $\mathrm{C}(45)$ & $6082(3)$ & $3609(3)$ & $4724(2)$ & $49(1)$ \\
\hline$C(46)$ & $6749(3)$ & $2704(3)$ & $5199(1)$ & $38(1)$ \\
\hline $\mathbf{N}(2 \mathbf{i})$ & $79064(2)$ & $553(2)$ & óis $7(1)$ & $52(1)$ \\
\hline $\operatorname{Si}(20)$ & $\pi 00 \pi(1)$ & $552(\hat{\mathbf{i}})$ & $6866(1)$ & $3 f(1)$ \\
\hline$C(2 i)$ & $55839(4)$ & $-80(93)$ & $6 \sin (2)$ & $55(1)$ \\
\hline$C(\Sigma \Sigma)$ & 6rio(4) & ก(24) & $355(2)$ & $62(2)$ \\
\hline$C(25)$ & $5743(4)$ & $\cos (3)$ & $6554(2)$ & $49(1)$ \\
\hline$N(22)$ & $10426(2)$ & $991(2)$ & $5598(1)$ & $28(1)$ \\
\hline C(20) & (1 $748(2)$ & $578(2)$ & $5992(1)$ & $S S(1)$ \\
\hline$C(24)$ & 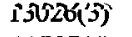 & $546(4)$ & $5509(2)$ & $59(1)$ \\
\hline$C(2 S)$ & n'787'4) & $-849(3)$ & б'só(2) & $58(1)$ \\
\hline$C(26)$ & 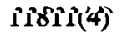 & $1520(4)$ & $646 \pi(2)$ & $59(1)$ \\
\hline $\mathrm{Na}(20)$ & $9264(1)$ & $-1042(1)$ & $5534(1)$ & $31(1)$ \\
\hline$O(20)$ & $8625(2)$ & $-2943(2)$ & $6106(1)$ & $37(1)$ \\
\hline$C(61)$ & $7454(3)$ & $-3409(3)$ & $5908(2)$ & $4)(3)$ \\
\hline$C(62)$ & $7190(4)$ & $-4545(3)$ & $6397(2)$ & $53(1)$ \\
\hline$C(63)$ & $8597(4)$ & $-5024(3)$ & $6688(2)$ & $57(1)$ \\
\hline$C(64)$ & $9133(3)$ & $-3756(3)$ & $6675(2)$ & $44(1)$ \\
\hline
\end{tabular}

${ }^{a}$ Equivalent isotrọbic $U$ defined as one third of the trace of the orthogonalized $J_{j}$-tensor

silyl)tert-butylamide [13,14], which has a butterfly-shaped structure, the four-membered MNSN rings fused to the central $\mathrm{M}_{2} \mathrm{~N}_{2}$ four-membered ring are above and below the plane of the central ring unit. The only monomeric derivatives known to 
Table 5

Atomic coordinates $\left(\times 10^{4}\right)$ and equivalent isotropic displacement coefficients $\left(\mathrm{pm}^{2} \times 10^{-1}\right)$ for 4

\begin{tabular}{|c|c|c|c|c|}
\hline & $x$ & $y$ & $z$ & $U_{\mathrm{eq}}{ }^{a}$ \\
\hline $\mathbf{K}(1)$ & $3163(1)$ & $5452(1)$ & $4694(1)$ & $36(1)$ \\
\hline$S(1)$ & $4130(1)$ & $4817(1)$ & $6306(1)$ & $30(1)$ \\
\hline$C(1)$ & $5600(3)$ & $5812(3)$ & $6545(1)$ & $29(1)$ \\
\hline$C(2)$ & $6786(3)$ & $5175(3)$ & $6795(1)$ & $36(1)$ \\
\hline$C(3)$ & $7919(3)$ & $5928(4)$ & $7010(2)$ & $42(1)$ \\
\hline$C(4)$ & $7867(3)$ & $7319(4)$ & $6977(2)$ & $44(1)$ \\
\hline$C(5)$ & $6690(4)$ & $7938(3)$ & $6737(2)$ & $47(1)$ \\
\hline$C(6)$ & $5552(3)$ & $7200(3)$ & $6522(2)$ & $40(1)$ \\
\hline $\mathrm{N}(1)$ & $3050(2)$ & $5884(3)$ & $5967(1)$ & $35(1)$ \\
\hline $\operatorname{Si}(1)$ & $1822(1)$ & $6361(1)$ & $6330(1)$ & $46(1)$ \\
\hline$C(11)$ & $190(3)$ & $6047(4)$ & $5781(2)$ & $54(1)$ \\
\hline $\mathrm{C}(12)$ & $1832(4)$ & $5493(7)$ & $7109(2)$ & $98(2)$ \\
\hline$C(13)$ & $1936(5)$ & $8185(5)$ & $6499(3)$ & $108(3)$ \\
\hline$N(2)$ & $4566(2)$ & $3877(2)$ & $5766(1)$ & $30(1)$ \\
\hline$C(20)$ & $4092(3)$ & $2454(3)$ & $5775(1)$ & $30(1)$ \\
\hline$C(21)$ & $4789(5)$ & $1715(4)$ & $6389(2)$ & $75(2)$ \\
\hline $\mathrm{C}(22)$ & $2631(4)$ & $2330(4)$ & $5718(3)$ & $75(2)$ \\
\hline$C(23)$ & $4459(6)$ & $1779(4)$ & $5194(3)$ & $87(2)$ \\
\hline$O(1)$ & $1504(3)$ & $7421(3)$ & $4128(2)$ & $78(1)$ \\
\hline$C(7)$ & $1369(5)$ & $8564(5)$ & $4506(2)$ & $80(2)$ \\
\hline$C(8)$ & $1170(7)$ & $9696(5)$ & $4075(2)$ & $108(3)$ \\
\hline$C(9)$ & $639(7)$ & $9119(5)$ & $3418(2)$ & $105(3)$ \\
\hline$C(10)$ & $849(5)$ & $7698(5)$ & $3478(2)$ & $80(2)$ \\
\hline
\end{tabular}

a Equivalent isotropic $U$ defined as one third of the trace of the orthogonalized $U_{i j}$ tensor

data are those of rhodium and palladium [15]. The derivatives 3-6 described here are all isostructural. At the centre of the $M_{2} \mathrm{~N}_{2}$ four-membered ring in each structure there is a centre of inversion. All the metals are coordinated by three nitrogen atoms and one THF molecule.

The distance between N1 and the metal is the shortest of the three metal-nitrogen distances since $\mathrm{N} 1$ is coordinated to one metal atom only. The N2 nitrogen atom is coordinated to two metal atoms, which results in longer nitrogen-metal distances. The shorter N2-metal distance is that to the symmetry equivalent M1a atom, whereas the distance between $\mathrm{M} 1$ and $\mathrm{N} 2$ is the longest metal-nitrogen distance in the dimeric structure. The average metal-nitrogen distance is $248.0 \mathrm{pm}$ in $3,282.2 \mathrm{pm}$ in $4,296.1 \mathrm{pm}$ in 5 , and $316.1 \mathrm{pm}$ in 6 . The difference in the metal-nitrogen distances between 3 and 4 is $34.2 \mathrm{pm}$, between 4 and $513.9 \mathrm{pm}$, and between 5 and $620.0 \mathrm{pm}$. These differences correspond to the differences in the radii of the metals $(\mathrm{Na} / \mathrm{K}: 40 \mathrm{pm} ; \mathrm{K} / \mathrm{Rb}: 15 \mathrm{pm} ; \mathrm{Rb} / \mathrm{Cs}: 20 \mathrm{pm})$ [16], and are also reflected in the metal-oxygen distances to the coordinated THF molecule. The nitrogen-sulphur distances in the anion are not as different as in structure $2 \mathrm{a}$. The same features as in structure $2 a$ are observed for the $\mathrm{N}-\mathrm{S}-\mathrm{C}$ angle, the shorter $\mathrm{S}-\mathrm{N}$ bond being associated with the larger angle.

One important feature of these structures is that the metals are four-coordinate in all cases, with a gap in the coordination sphere of the metal filled by the $\pi$-electron system of the phenyl substituent. The distance between metal and centre of the phenyl ring decreases on going from the sodium derivative $3(386.3 \mathrm{pm})$ to the 
Table 6

Atomic coordinates $\left(\times 10^{4}\right)$ and equivalent isotropic displacement coefficients $\left(\mathrm{pm}^{2} \times 10^{-1}\right)$ for 5

\begin{tabular}{lllll}
\hline & $x$ & $y$ & $z$ & $U_{\text {eq }}{ }^{a}$ \\
\hline $\mathrm{Rb}(1)$ & $5522(1)$ & $3430(1)$ & $5826(1)$ & $58(1)$ \\
$\mathrm{S}(1)$ & $5377(1)$ & $3123(1)$ & $2511(1)$ & $55(1)$ \\
$\mathrm{C}(1)$ & $6332(3)$ & $4582(3)$ & $2352(3)$ & $39(1)$ \\
$\mathrm{C}(2)$ & $5708(4)$ & $5342(3)$ & $1637(3)$ & $55(1)$ \\
$\mathrm{C}(3)$ & $6413(4)$ & $6449(4)$ & $1481(4)$ & $68(2)$ \\
$\mathrm{C}(4)$ & $7742(4)$ & $6788(3)$ & $2022(4)$ & $68(2)$ \\
$\mathrm{C}(5)$ & $8375(3)$ & $6034(4)$ & $2725(4)$ & $60(1)$ \\
$\mathrm{C}(6)$ & $7663(3)$ & $4911(3)$ & $2879(3)$ & $48(1)$ \\
$\mathrm{N}(1)$ & $6408(3)$ & $2605(3)$ & $3452(4)$ & $80(2)$ \\
$\mathrm{Si}(1)$ & $7200(2)$ & $1283(2)$ & $3342(2)$ & $39(1)$ \\
$\mathrm{Si}\left(1^{\prime}\right)$ & $6549(2)$ & $945(2)$ & $2596(2)$ & $37(1)$ \\
$\mathrm{C}(11)$ & $6055(5)$ & $-101(4)$ & $3490(5)$ & $91(2)$ \\
$\mathrm{C}(12)$ & $8091(5)$ & $961(5)$ & $2063(6)$ & $130(3)$ \\
$\mathrm{C}(13)$ & $8575(7)$ & $1369(8)$ & $4698(7)$ & $69(3)$ \\
$\mathrm{C}\left(13^{\prime}\right)$ & $5575(11)$ & $110(8)$ & $1017(7)$ & $81(4)$ \\
$\mathrm{N}(2)$ & $4234(3)$ & $3759(2)$ & $3229(3)$ & $48(1)$ \\
$\mathrm{Si}(2)$ & $2632(1)$ & $2965(1)$ & $2911(1)$ & $47(1)$ \\
$\mathrm{C}(21)$ & $2090(4)$ & $2037(4)$ & $1240(4)$ & $67(2)$ \\
$\mathrm{C}(22)$ & $2390(4)$ & $1802(3)$ & $3930(4)$ & $64(2)$ \\
$\mathrm{C}(23)$ & $1478(3)$ & $4199(3)$ & $3297(4)$ & $58(1)$ \\
$\mathrm{O}(1)$ & $7228(3)$ & $2937(3)$ & $7987(3)$ & $91(1)$ \\
$\mathrm{C}(7)$ & $7516(9)$ & $1662(8)$ & $8203(10)$ & $71(4)$ \\
$\mathrm{C}\left(7^{\prime}\right)$ & $7975(10)$ & $1893(9)$ & $7557(9)$ & $70(4)$ \\
$\mathrm{C}(8)$ & $8795(5)$ & $1814(4)$ & $8839(5)$ & $78(2)$ \\
$\mathrm{C}(9)$ & $8996(5)$ & $3206(4)$ & $9619(5)$ & $85(2)$ \\
$\mathrm{C}(10)$ & $7723(5)$ & $3680(5)$ & $9217(4)$ & $84(2)$ \\
\hline
\end{tabular}

“ Equivalent isotropic $U$ defined as one third of the trace of the orthogonalized $U_{i j}$ tensor.

caesium derivative $6(355.1 \mathrm{pm})$ by $31.2 \mathrm{pm}$. This fall in the strength of the weak metal-ring interaction [16,17], is caused by three structural factors:

(a) Of the $\mathrm{M}-\mathrm{N}$ distances the $\mathrm{M} 1-\mathrm{N} 2 \mathrm{a}$ distance increases more than the average, which enables the metal to move from the ipso-carbon atom to the ring centre.

(b) The angle between the normals of the $\mathrm{N}_{2} \mathrm{M}_{2}$ and the MNSN planes narrows increasingly on going from 3 to 6 . This allows the phenyl ring in 6 to lie closer to the metal than in 3, although the angle between the $\mathrm{S} 1-\mathrm{Cl}$ bond and the plane NSN defined by $\mathrm{N} 1-\mathrm{S} 1-\mathrm{N} 2$ remains constant.

(c) The torsion angle $\mathrm{N} 1-\mathrm{S} 1-\mathrm{C} 1-\mathrm{C} 6$ shows that the phenyl ring turns towards the metal. The vector between the ring centre and metal forms and angle of $49.1^{\circ}$ to the phenyl ring plane in 3 , compared with $77.6^{\circ}$ in 6 , i.e. shows that this vector moves towards perpendicularity.

In addition to these steric effects there is also a significant electronic effect. The interaction of alkali metal cations with $\pi$-electron systems increases with increasing atomic number $[16,18 *]$.

Replacement of the t-butyl substituent at the $\mathrm{N} 2$ nitrogen atom by a trimethylsilyl groups has no significant influence on the structure, but replacement of the

\footnotetext{
* Reference number with asterisk indicates a note in the list of references.
} 
Table 7

Atomic coordinates $\left(\times 10^{4}\right)$ and equivalent isotropic displacement coefficients $\left(\mathrm{pm}^{2} \times 10^{-1}\right)$ for 6

\begin{tabular}{llllr}
\hline & $x$ & $y$ & $z$ & $U_{\text {eq }}{ }^{a}$ \\
\hline $\mathrm{Cs}(1)$ & $5505(1)$ & $3293(1)$ & $5540(1)$ & $53(1)$ \\
$\mathrm{S}(1)$ & $5091(1)$ & $3137(1)$ & $3809(1)$ & $47(1)$ \\
$\mathrm{C}(1)$ & $5826(4)$ & $4496(4)$ & $347092)$ & $52(1)$ \\
$\mathrm{C}(2)$ & $5127(6)$ & $5133(5)$ & $3014(2)$ & $72(2)$ \\
$\mathrm{C}(3)$ & $5657(8)$ & $6230(6)$ & $2778(3)$ & $91(2)$ \\
$\mathrm{C}(4)$ & $6851(9)$ & $6672(6)$ & $2990(3)$ & $101(3)$ \\
$\mathrm{C}(5)$ & $7534(7)$ & $6025(6)$ & $3444(3)$ & $92(2)$ \\
$\mathrm{C}(6)$ & $7045(5)$ & $4929(5)$ & $3680(2)$ & $68(2)$ \\
$\mathrm{N}(1)$ & $6245(3)$ & $2612(3)$ & $4248(2)$ & $51(1)$ \\
$\mathrm{Si}(1)$ & $7042(1)$ & $1258(1)$ & $4084(1)$ & $59(1)$ \\
$\mathrm{C}(11)$ & $7912(8)$ & $1301(7)$ & $3344(3)$ & $114(3)$ \\
$\mathrm{C}(12)$ & $5938(7)$ & $-125(5)$ & $4047(4)$ & $115(3)$ \\
$\mathrm{C}(13)$ & $8331(7)$ & $1041(7)$ & $4705(3)$ & $100(3)$ \\
$\mathrm{N}(2)$ & $4020(3)$ & $3807(3)$ & $4222(2)$ & $46(1)$ \\
$\mathrm{Si}(2)$ & $2409(1)$ & $3379(1)$ & $4139(1)$ & $62(1)$ \\
$\mathrm{C}(21)$ & $1556(8)$ & $3979(17)$ & $4755(6)$ & $291(9)$ \\
$\mathrm{C}(22)$ & $2139(10)$ & $1723(7)$ & $4020(10)$ & $276(13)$ \\
$\mathrm{C}(23)$ & $1601(9)$ & $4106(16)$ & $3459(6)$ & $243(8)$ \\
$\mathrm{O}(1)$ & $7690(5)$ & $2039(6)$ & $6361(3)$ & $126(2)$ \\
$\mathrm{C}(7)$ & $9081(8)$ & $2099(13)$ & $6331(4)$ & $158(5)$ \\
$\mathrm{C}(8)$ & $9608(8)$ & $1752(9)$ & $6883(4)$ & $133(4)$ \\
$\mathrm{C}(9)$ & $9657(8)$ & $973(8)$ & $7179(4)$ & $112(3)$ \\
$\mathrm{C}(10)$ & $7384(7)$ & $1399(8)$ & $6873(4)$ & $108(3)$ \\
\hline
\end{tabular}

a Equivalent isotropic $U$ defined as one third of the trace of the orthogonalized $U_{i j}$ tensor.

phenyl group bonded to the sulphur atom by a t-butyl group has a marked structural effect.

\section{Crystal structures of the lithium derivatives 7 and 8}

The structures of 7 and 8 are shown in Figs. 6 and 7. Again crystallographic data are given in Table 1, and selected bond lengths and angles in Table 8. Tables 9 and 10 list the fractional coordinates.

Although the presence of one diethyl ether molecule is observed in the ${ }^{1}$ H NMR spectra of 1a and 1b, solid lithium derivatives 7 and 8 contain no coordinated ether even though the syntheses were performed in this solvent (Figs. 6 and 7).

Compound 7, with two trimethylsilyl groups bonded to the nitrogen atoms, still has the step-shaped structure of the other alkali metal derivatives 3-6 (Table 8), although the distance between Li1 and N2 is rather long compared to other lithium-nitrogen bond lengths.

The distance across the ring is $43 \mathrm{pm}$ longer than the other two lithium-nitrogen distances. In 8 the corresponding distance is $89 \mathrm{pm}$ longer $(279.6 \mathrm{pm})$. For this reason we prefer to describe the structure of 8 as involving an eight-membered ring than being step-shaped. In this case the metal is clearly coordinated by only two nitrogen atoms. This difference must be ascribed to the difference in the electronic properties of the substituents at the nitrogen atom, since they have almost the same bulk. 


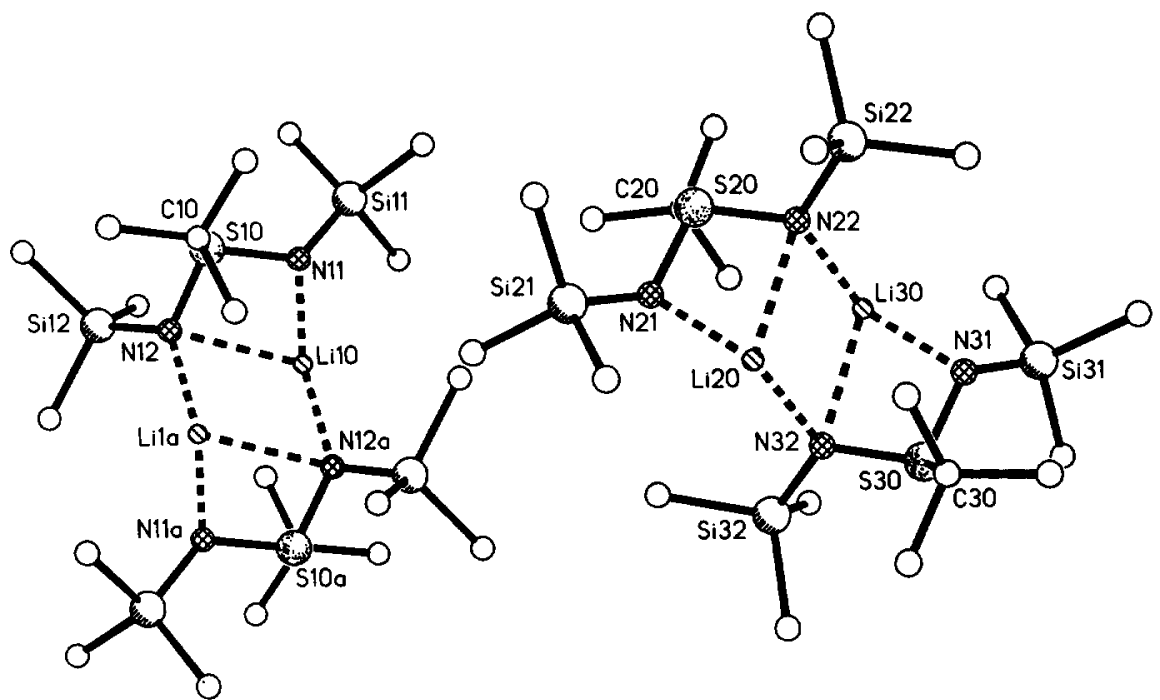

Fig. 6. Crystal structure of 7. In the Discussion the chemically-equivalent atoms S10 and S20 are referred to S1, N11 and N2, as N1, etc.

In the case of $\mathrm{R}=\mathrm{SiMe}_{3}$ (7), the Li1-N2a bond length is $196.5 \mathrm{pm}$, while in 8 $\left(\mathrm{R}={ }^{\mathrm{t}} \mathrm{Bu}\right)$ it is only $191.2 \mathrm{pm}$. A trimethylsilyl group bonded to the nitrogen atom is less electron releasing than the tert-butyl group, and so the metal seeks to form an interaction with a third nitrogen atom across the eight-membered ring. This view is supported by the fact that there are two signals for the $\mathrm{SiMe}_{3}$ groups in the ${ }^{1} \mathrm{H}$ and ${ }^{13} \mathrm{C}$ NMR spectra. One of them is ascribed to the quarternary nitrogen atom, the other to the trigonally-coordinated nitrogen atom. The $\mathbf{S}-\mathbf{N}$ distances are not
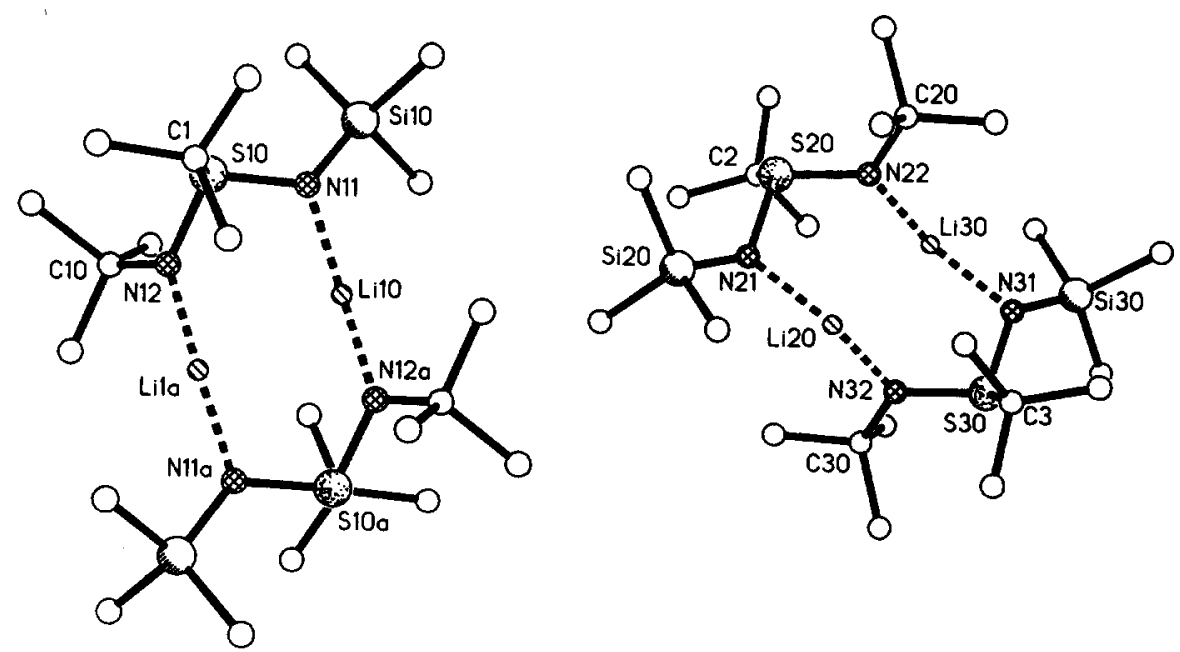

Fig. 7. Crystal structure of 8. In the Discussion the chemically-equivalent atoms $\mathbf{S 1 0}$ and $\mathbf{2 0}$ are referred to $\mathrm{S} 1, \mathrm{~N} 11$ and $\mathrm{N} 21$ as N1, etc. 
Table 8

Selected bond lengths (pm) and angles $\left({ }^{\circ}\right)$ for 7 and 8

\begin{tabular}{llr}
\hline & $7^{a}$ & $8^{a}$ \\
\hline Li1-N1 & $191.6(7)$ & $190.4(7)$ \\
Li1-N2a & $196.5(6)$ & $191.2(7)$ \\
Li1-N2 & $237.4(8)$ & $(279.6)^{b}$ \\
S1-N1 & $160.5(3)$ & $160.3(3)$ \\
S1-N2 & $162.4(3)$ & $162.5(3)$ \\
S1-C1 & $185.4(3)$ & $186.5(3)$ \\
N1-Li1-N2a & $140.6(4)$ & $149.1(4)$ \\
N1-S1-N2 & $105.7(1)$ & $107.1(1)$ \\
N1-S1-C1 & $104.1(1)$ & $104.1(1)$ \\
N2-S1-C1 & $103.4(1)$ & $102.0(2)$ \\
C1-P $_{\text {NSN }}{ }^{c}$ & 113.5 & 112.4 \\
P $_{\text {NSNM }}-P_{\text {NMNM }}{ }^{d}$ & 137.5 &
\end{tabular}

${ }^{a}$ Average values of three independent molecules; esd's reflect the extreme values. ${ }^{b}$ Non-bonded distance. ' Angle between the S1-Cl vector and the plane defined by N1-S1-N2. ${ }^{d}$ Angle between the four-membered ring units M1-N1-S1-N2 and M1-N2-M1a-N2a.

significantly different, but for steric reasons the $\mathrm{S}-\mathrm{C}$ bonds are $4 \mathrm{pm}$ longer than those in compounds 2a-6 (see Tables 2 and 8). For the same reason the angle between the S-C bond and the NSN plane is $3^{\circ}$ larger than those in 2a-6.

Because of the very bulky substituents, which surround the lithium atoms like a basket, there are short $\mathrm{Li}-\mathrm{H}$ distances $(240-270 \mathrm{pm})$. The lithium atoms are sterically so well protected that no ether molecule can coordinate to it.

\section{Experimental section}

All experiments were carried out under dry argon with strict exclusion of air and moisture. Mass spectra: Varian CH5-spectrometer. ${ }^{1} \mathrm{H},{ }^{7} \mathrm{Li},{ }^{13} \mathrm{C},{ }^{133} \mathrm{Cs}$ NMR: $10 \%$ solutions in $\mathrm{C}_{7} \mathrm{D}_{8}\left(2 \mathrm{a}, \mathbf{2 b}: \mathrm{CDCl}_{3} ; 7: \mathrm{C}_{6} \mathrm{D}_{6}\right),{ }^{29} \mathrm{Si}-\mathrm{NMR}: 20 \%$ solutions in $\mathrm{CDCl}_{3}$ (7: $\mathrm{C}_{6} \mathrm{D}_{6}$ ); TMS, LiCl, CsF external, Bruker AM $250\left({ }^{1} \mathrm{H}-\mathrm{NMR}\right.$ of 2a: WP $80 \mathrm{SY}$ ).

2a, $2 b$ : A solution of $0.1 \mathrm{~mol}$ of $\mathrm{R}-\mathrm{N}=\mathrm{S}=\mathrm{N}-\mathrm{SiMe}_{3}\left(2 \mathrm{a}: \mathrm{R}={ }^{\mathrm{t}} \mathrm{C}_{4} \mathrm{H}_{9}, 2 \mathrm{~b}: \mathrm{R}=\right.$ $\left.\mathrm{SiMe}_{3}\right)$ in $50 \mathrm{ml}$ of hexane is cooled to $-60^{\circ} \mathrm{C}$ and $0.1 \mathrm{~mol}$ of $\mathrm{C}_{6} \mathrm{H}_{5} \mathrm{Li}(2 \mathrm{M}$ solution in $\mathrm{Et}_{2} \mathrm{O} /$ cyclohexane) is added. The mixture is refluxed for $2 \mathrm{~h}$. The lithium derivate (1a, 1b) formed is hydrolysed with $0.1 \mathrm{~mol}$ of $\mathrm{H}_{2} \mathrm{O}, \mathrm{LiOH}$ is filtered off, the solvent evaporated off and the residue recrystallized from hexane.

3, 4: A solution of $0.01 \mathrm{~mol}$ of $2 \mathrm{a}$ in $20 \mathrm{ml}$ of hexane is added to a suspension of $0.011 \mathrm{~mol} \mathrm{NaH} \mathrm{(3)}$ or $\mathrm{KH}(4)$ in $0.04 \mathrm{~mol}$ of THF and $30 \mathrm{ml}$ hexane. The mixture is refluxed for $5 \mathrm{~h}$ and the excess of hydride then removed by filtration. The product is isolated and then recrystallized from hexane.

5, 6: A solution of an equimolar amount of $2 \mathrm{~b}(0.012 \mathrm{~mol}$ for the preparation of $5,0.0075 \mathrm{~mol}$ for 6 ) in $20 \mathrm{ml}$ of hexane is added dropwise to a suspension of $1 \mathrm{~g} \mathrm{Rb}$ (5) or Cs (6) in $30 \mathrm{ml}$ of hexane/THF. The mixture is refluxed for $5 \mathrm{~h}$ then filtered through a glass frit. The product is isolated and then recrystallized from the reaction solution. 
Table 9

Atomic coordinates $\left(\times 10^{4}\right)$ and equivalent isotropic displacement coefficients $\left(\mathrm{pm}^{2} \times 10^{-1}\right)$ for 7

\begin{tabular}{|c|c|c|c|c|}
\hline & $x$ & $y$ & $z$ & $U_{\text {eq }}{ }^{a}$ \\
\hline$S(10)$ & $4332(1)$ & $6293(1)$ & $-1517(1)$ & $34(1)$ \\
\hline$C(10)$ & $2290(3)$ & $6366(2)$ & $-1363(2)$ & $52(1)$ \\
\hline$C(17)$ & $1969(4)$ & $7294(2)$ & $-1657(2)$ & $82(2)$ \\
\hline$C(18)$ & $1864(3)$ & $5838(2)$ & $-456(2)$ & $69(2)$ \\
\hline$C(19)$ & $1520(3)$ & $6076(2)$ & $-1912(2)$ & $86(2)$ \\
\hline $\mathrm{N}(11)$ & $5075(2)$ & $6606(1)$ & $-919(1)$ & $38(1)$ \\
\hline $\mathrm{Si}(11)$ & $6228(1)$ & $7459(1)$ & $-1266(1)$ & $46(1)$ \\
\hline $\mathrm{C}(11)$ & $7903(3)$ & $7087(2)$ & $-586(2)$ & $72(2)$ \\
\hline $\mathrm{C}(12)$ & $6856(5)$ & $7844(2)$ & $-2358(2)$ & $102(2)$ \\
\hline$C(13)$ & $5338(4)$ & $8321(2)$ & $-1125(3)$ & $93(2)$ \\
\hline$N(12)$ & $4649(2)$ & $5293(1)$ & $-1092(1)$ & $36(1)$ \\
\hline $\mathrm{Si}(12)$ & $5533(1)$ & $4977(1)$ & $-1752(1)$ & $45(1)$ \\
\hline$C(14)$ & $4603(4)$ & $5379(2)$ & $-2777(2)$ & $82(2)$ \\
\hline$C(15)$ & $7520(3)$ & $5320(2)$ & $-1949(2)$ & $70(2)$ \\
\hline$C(16)$ & $5457(4)$ & $3812(2)$ & $-1239(2)$ & $67(2)$ \\
\hline $\operatorname{Li}(10)$ & $5772(7)$ & $5567(3)$ & $-49(4)$ & $79(3)$ \\
\hline$S(20)$ & $664(1)$ & $8739(1)$ & $1667(1)$ & $32(1)$ \\
\hline$C(20)$ & $2695(3)$ & $8759(2)$ & $1417(2)$ & $42(1)$ \\
\hline $\mathrm{C}(27)$ & $3103(3)$ & $9674(2)$ & $910(2)$ & $77(2)$ \\
\hline $\mathrm{C}(28)$ & $3618(3)$ & $8345(2)$ & $2196(2)$ & $59(1)$ \\
\hline$C(29)$ & $2867(4)$ & $8288(2)$ & $917(2)$ & $74(2)$ \\
\hline $\mathrm{N}(21)$ & $258(2)$ & $7761(1)$ & $2131(1)$ & $40(1)$ \\
\hline $\mathrm{Si}(21)$ & $-1142(1)$ & $7323(1)$ & $1831(1)$ & $46(1)$ \\
\hline $\mathrm{C}(21)$ & $-371(5)$ & $6508(2)$ & $1585(3)$ & $107(3)$ \\
\hline $\mathrm{C}(22)$ & $-2476(4)$ & $6821(2)$ & $2733(2)$ & $90(2)$ \\
\hline$C(23)$ & $-2229(3)$ & $8092(2)$ & $940(2)$ & $50(1)$ \\
\hline$N(22)$ & $617(2)$ & $9039(1)$ & $2376(1)$ & $35(1)$ \\
\hline $\mathrm{Si}(22)$ & $-615(1)$ & $9860(1)$ & $2172(1)$ & $40(1)$ \\
\hline$C(24)$ & $-299(4)$ & $10767(2)$ & $1126(2)$ & $67(2)$ \\
\hline$C(25)$ & $-297(4)$ & $10230(2)$ & $2951(2)$ & $72(2)$ \\
\hline$C(26)$ & $-2601(3)$ & $9535(2)$ & $2223(2)$ & $66(2)$ \\
\hline $\mathrm{Li}(20)$ & $125(6)$ & $7602(3)$ & $3243(3)$ & $68(3)$ \\
\hline$S(30)$ & $1338(1)$ & $7433(1)$ & $4963(1)$ & $40(1)$ \\
\hline$C(30)$ & $-681(3)$ & $7396(2)$ & $5238(2)$ & $53(1)$ \\
\hline$C(38)$ & $-1116(4)$ & $6477(2)$ & $5688(2)$ & $83(2)$ \\
\hline $\mathrm{C}(39)$ & $-804(4)$ & $7793(3)$ & $5806(2)$ & $88(2)$ \\
\hline$N(31)$ & $1715(2)$ & $8413(1)$ & $4498(1)$ & $43(1)$ \\
\hline $\mathrm{Si}(31)$ & $3050(1)$ & $8879(1)$ & $4809(1)$ & $54(1)$ \\
\hline$C(31)$ & $4189(4)$ & $8135(2)$ & $5693(2)$ & $93(2)$ \\
\hline$C(32)$ & $4348(4)$ & $9441(2)$ & $3906(2)$ & $93(2)$ \\
\hline$C(33)$ & $2200(5)$ & $9675(3)$ & $5056(3)$ & $122(4)$ \\
\hline$N(32)$ & $1359(2)$ & $7145(1)$ & $4243(1)$ & $38(1)$ \\
\hline $\mathrm{Si}(32)$ & $2547(1)$ & $6303(1)$ & $4451(1)$ & $48(1)$ \\
\hline$C(34)$ & $2333(4)$ & $5999(2)$ & $3616(2)$ & $74(2)$ \\
\hline$C(35)$ & $4543(3)$ & $6573(2)$ & $4507(2)$ & $74(2)$ \\
\hline$C(36)$ & $2096(4)$ & $5359(2)$ & $5446(2)$ & $75(2)$ \\
\hline $\operatorname{Li}(30)$ & $1816(6)$ & $8562(3)$ & $3388(3)$ & $66(3)$ \\
\hline
\end{tabular}

\footnotetext{
${ }^{a}$ Equivalent isotropic $U$ defined as one third of the trace of the orthogonalized $U_{i i}$ tensor.
} 
Table 10

Atomic coordinates $\left(\times 10^{4}\right)$ and equivalent isotropic displacement coefficients $\left(\mathrm{pm}^{2} \times 10^{-1}\right)$ for 8

\begin{tabular}{|c|c|c|c|c|}
\hline$S(10)$ & $10495(1)$ & $6276(1)$ & $6617(1)$ & $34(1)$ \\
\hline$C(1)$ & $12626(3)$ & $6365(2)$ & $6540(2)$ & $43(1)$ \\
\hline$C(17)$ & $12950(4)$ & $7295(2)$ & $6779(2)$ & $63(2)$ \\
\hline$C(18)$ & $13166(3)$ & $5763(2)$ & $5656(2)$ & $64(2)$ \\
\hline$C(19)$ & $13342(3)$ & $6135(2)$ & $7171(2)$ & $60(2)$ \\
\hline $\mathrm{N}(11)$ & $9800(3)$ & $6573(1)$ & $5973(1)$ & $41(1)$ \\
\hline $\operatorname{Si}(10)$ & $8644(1)$ & $7437(1)$ & $6291(1)$ & $38(1)$ \\
\hline$C(11)$ & $7052(4)$ & $7085(2)$ & $5545(2)$ & $62(2)$ \\
\hline$C(12)$ & $7866(5)$ & $7843(2)$ & $7349(2)$ & $84(2)$ \\
\hline$C(13)$ & $9631(4)$ & $8317(2)$ & $6219(3)$ & $80(2)$ \\
\hline$N(12)$ & $10241(3)$ & $5240(1)$ & $6195(1)$ & $41(1)$ \\
\hline$C(10)$ & $9257(2)$ & $4978(1)$ & $6702(1)$ & $41(1)$ \\
\hline$C(14)$ & $9952(4)$ & $5277(2)$ & $7636(2)$ & $60(2)$ \\
\hline$C(15)$ & $7541(4)$ & $5315(2)$ & $6823(2)$ & $55(2)$ \\
\hline$C(16)$ & $9239(4)$ & $3961(2)$ & $6254(2)$ & $62(2)$ \\
\hline $\operatorname{Li}(10)$ & $9238(7)$ & $5634(4)$ & $4910(4)$ & $72(3)$ \\
\hline$S(20)$ & $4577(1)$ & $8761(1)$ & $3334(1)$ & $34(1)$ \\
\hline $\mathrm{C}(2)$ & $2488(3)$ & $8771(2)$ & $4597(2)$ & $40(1)$ \\
\hline $\mathrm{C}(27)$ & $2123(4)$ & $9693(2)$ & $4234(2)$ & $57(2)$ \\
\hline $\mathrm{C}(28)$ & $1473(3)$ & $8472(2)$ & $2817(2)$ & $61(2)$ \\
\hline$C(29)$ & $2328(4)$ & $8181(2)$ & $3981(2)$ & $62(2)$ \\
\hline $\mathrm{N}(21)$ & $4989(3)$ & $7760(1)$ & $2794(1)$ & $40(1)$ \\
\hline $\operatorname{Si}(20)$ & $6384(1)$ & $7301(1)$ & $3101(1)$ & $35(1)$ \\
\hline$C(21)$ & $5537(4)$ & $6432(2)$ & $3233(3)$ & $69(2)$ \\
\hline $\mathrm{C}(22)$ & $7767(5)$ & $6825(2)$ & $2254(2)$ & $72(2)$ \\
\hline$C(23)$ & $7388(4)$ & $8034(2)$ & $4052(2)$ & $57(2)$ \\
\hline $\mathrm{N}(22)$ & $4523(3)$ & $9155(2)$ & $2686(1)$ & $42(1)$ \\
\hline$C(20)$ & $5737(2)$ & $9842(1)$ & $2856(1)$ & $44(1)$ \\
\hline $\mathrm{C}(24)$ & $5445(4)$ & $10685(2)$ & $3777(2)$ & $60(2)$ \\
\hline$C(25)$ & $5515(5)$ & $10166(2)$ & $2198(2)$ & $71(2)$ \\
\hline$C(26)$ & $7445(4)$ & $9545(2)$ & $2864(2)$ & $59(2)$ \\
\hline $\mathrm{Li}(20)$ & 4821(7) & $7404(5)$ & $1630(4)$ & $75(3)$ \\
\hline$S(30)$ & $3553(1)$ & $7370(1)$ & $-16(1)$ & $39(1)$ \\
\hline$C(3)$ & $5651(3)$ & $7337(2)$ & $-268(2)$ & $46(1)$ \\
\hline$C(37)$ & $6631(3)$ & $7707(2)$ & $528(2)$ & $59(2)$ \\
\hline$C(38)$ & $6044(4)$ & $6401(2)$ & $-830(2)$ & $66(2)$ \\
\hline$C(39)$ & $5830(4)$ & $7849(2)$ & $-729(2)$ & $67(2)$ \\
\hline$N(31)$ & $3180(3)$ & $8375(2)$ & $514(1)$ & $43(1)$ \\
\hline $\operatorname{Si}(30)$ & $1875(1)$ & $8882(1)$ & $213(1)$ & $42(1)$ \\
\hline$C(31)$ & $659(4)$ & $8173(2)$ & $-679(2)$ & $76(2)$ \\
\hline$C(32)$ & $627(5)$ & $9497(3)$ & $1121(3)$ & $92(2)$ \\
\hline$C(33)$ & $2814(5)$ & $9665(3)$ & $-14(4)$ & $116(4)$ \\
\hline$N(32)$ & $3553(3)$ & $6989(2)$ & $639(1)$ & $45(1)$ \\
\hline$C(30)$ & $2375(2)$ & $6296(1)$ & $449(1)$ & $47(1)$ \\
\hline$c(34)$ & $2509(5)$ & $5998(2)$ & $1136(2)$ & $71(2)$ \\
\hline$C(35)$ & $641(4)$ & $6602(2)$ & $439(2)$ & $61(2)$ \\
\hline$C(36)$ & $2640(5)$ & $5453(2)$ & $-444(2)$ & $71(2)$ \\
\hline Li(30) & $3266(7)$ & $8732(5)$ & $1685(3)$ & $76(3)$ \\
\hline
\end{tabular}

\footnotetext{
"Equivalent isotropic $U$ defined as one third of the trace of the orthogonalized $U_{i j}$ tensor.
} 
7, 8: A solution of $0.01 \mathrm{~mol}$ of ${ }^{\prime} \mathrm{C}_{4} \mathrm{H}_{9} \mathrm{Li}$ (1.5 M solution in pentane) in $0.04 \mathrm{~mol}$ $\mathrm{Et}_{2} \mathrm{O}$ is added at $-60^{\circ} \mathrm{C}$ to a solution of $0.01 \mathrm{~mol}$ of $\mathrm{R}-\mathrm{N}=\mathrm{S}=\mathrm{N}-\mathrm{SiMe}_{3}$ (7: $\mathrm{R}=\mathrm{SiMe}_{3}, 8: \mathrm{R}={ }^{1} \mathrm{C}_{4} \mathrm{H}_{9}$ ) in $50 \mathrm{ml}$ of pentane. The mixture is refluxed for $1 \mathrm{~h}$. The mixture is set aside for 4 days during which crystals of 7 or 8 separate.

\section{$\mathrm{N}$-Trimethylsilyl-N'-tert-butyl-S-phenyl-sulfiniminamine (2a)}

M.p. $84-86^{\circ} \mathrm{C}$. Yield $14.77 \mathrm{~g}(55.1 \%)$. MS: $m / z(\%)=268(18)[M]^{+}$, FI-method: $m / z(\mathscr{\%})=268(100)[M]^{+} .{ }^{1} \mathrm{H}$ NMR: $\delta=0.19\left(\mathrm{~s}, \mathrm{SiMe}_{3}\right) ; 1.36\left(\mathrm{~s},{ }^{\prime} \mathrm{C}_{4} \mathrm{H}_{9}\right) ; 7.35-7.80$

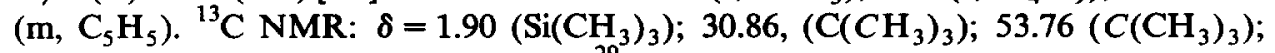
126.06, 128.26, 129.59, $148.03\left(\mathrm{C}_{6} \mathrm{H}_{5}\right) .{ }^{29} \mathrm{Si} \mathrm{NMR:} \delta=0.56\left(\mathrm{SiMe}_{3}\right)$.

\section{$\mathrm{N}, \mathrm{N}^{\prime}$-Bis-trimethylsilyl-S-phenyl-sulfiniminamine (2b)}

M.p. $92-94^{\circ} \mathrm{C}$. Yield $12.95 \mathrm{~g}(45.6 \%)$. MS: $m / z(\%)=284(24)[M]^{+}$, FI-method: $m / z(\%)=284(100)[M]^{+} .{ }^{1} \mathrm{H}$ NMR: $\delta=0.23\left(\mathrm{~s}, \mathrm{SiMe}_{3}\right) ; 7.35-7.71\left(\mathrm{~m}, \mathrm{C}_{6} \mathrm{H}_{5}\right) \cdot{ }^{13} \mathrm{C}$ NMR: $\delta=1.63\left(\mathrm{Si}\left(\mathrm{CH}_{3}\right)_{3}\right) ; 125.71,128.67,129.83,150.68\left(\mathrm{C}_{6} \mathrm{H}_{5}\right) .{ }^{29} \mathrm{Si}$ NMR: $\delta=5.01\left(\mathrm{SiMe}_{3}\right)$.

Bis(sodium-N-trimethylsilyl-N'-tert-butyl-S-phenylsulfinimidamide-tetrahydrofuran) (3)

Yield $3.26 \mathrm{~g}(90 \%) .{ }^{1} \mathrm{H}$ NMR: $\delta=0.24\left(\mathrm{~s}, \mathrm{SiMe}_{3}\right) ; 1.22\left(\mathrm{~s},{ }^{\prime} \mathrm{C}_{4} \mathrm{H}_{9}\right) ; 1.27$ (t, $\left.\mathrm{O}\left(\mathrm{CH}_{2}\right)_{2}\left(\mathrm{CH}_{2}\right)_{2}\right) ; 3.55\left(\mathrm{t}, \mathrm{O}\left(\mathrm{CH}_{2}\right)_{2}\left(\mathrm{CH}_{2}\right)_{2}\right) ; 7.16-7.84\left(\mathrm{~m}, \mathrm{C}_{6} \mathrm{H}_{5}\right) ;{ }^{13} \mathrm{C}$ NMR: $\left.\delta=1.35,2.69\left(\mathrm{Si}\left(\mathrm{CH}_{3}\right)_{3}\right) ; 29.00\left(\mathrm{O}\left(\mathrm{CH}_{2}\right)_{2}\left(\mathrm{CH}_{2}\right)_{2}\right) ; 30.80\left(\mathrm{C}_{(\mathrm{CH}}\right)_{3}\right) ; \quad 53.64$ $\left(\mathrm{C}\left(\mathrm{CH}_{3}\right)_{3}\right) ; 67.50\left(\mathrm{O}\left(\mathrm{CH}_{2}\right)_{2}\left(\mathrm{CH}_{2}\right)_{2}\right) ; 126.53,128.32,137.45,149.53\left(\mathrm{C}_{6} \mathrm{H}_{5}\right)$.

Bis(potassium-N-trimethylsilyl-N'-tert-butyl-S-phenylsulfinimidamide-tetrahydrofuran) (4)

Yield $3.40 \mathrm{~g}(90 \%) .{ }^{1} \mathrm{H}$ NMR: $\delta=0.29\left(\mathrm{~s}, \mathrm{SiMe}_{3}\right) ; 1.22\left(\mathrm{~s},{ }^{\mathrm{t}} \mathrm{C}_{4} \mathrm{H}_{9}\right) ; 1.43(\mathrm{t}$, $\left.\mathrm{O}\left(\mathrm{CH}_{2}\right)_{2}\left(\mathrm{CH}_{2}\right)_{2}\right) ; 3.54\left(\mathrm{t}, \mathrm{O}\left(\mathrm{CH}_{2}\right)_{2}\left(\mathrm{CH}_{2}\right)_{2}\right) ; 6.97-7.75\left(\mathrm{~m}, \mathrm{C}_{6} \mathrm{H}_{5}\right)$. ${ }^{13} \mathrm{C}$ NMR:

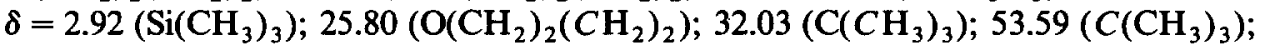
$67.73\left(\mathrm{O}\left(\mathrm{CH}_{2}\right)_{2}\left(\mathrm{CH}_{2}\right)_{2}\right) ; 126.22,137.47\left(\mathrm{C}_{6} \mathrm{H}_{5}\right)$.

Bis(rubidium-N,N'-bis(trimethylsilyl)-S-phenyl-sulfinimidamidetetrahydrofuran) (5)

Yield $3.22 \mathrm{~g} \mathrm{(61 \% ).}{ }^{1} \mathrm{H}$ NMR: $\delta=0.16\left(\mathrm{~s}, \mathrm{SiMe}_{3}\right) ; 1.44\left(\mathrm{t},\left(\mathrm{O}\left(\mathrm{CH}_{2}\right)_{2}\left(\mathrm{CH}_{2}\right)_{2}\right)\right.$; 3.51 (t, $\left.\mathrm{O}\left(\mathrm{CH}_{2}\right)_{2}\left(\mathrm{CH}_{2}\right)_{2}\right) ; 7.19-7.76\left(\mathrm{~m}, \mathrm{C}_{6} \mathrm{H}_{5}\right) .{ }^{13} \mathrm{C} \mathrm{NMR}: \delta=3.38\left(\mathrm{Si}\left(\mathrm{CH}_{3}\right)_{3}\right)$;

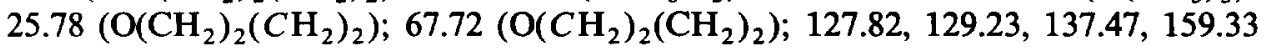
$\left(\mathrm{C}_{6} \mathrm{H}_{5}\right)$.

Bis(caesium-N,N'-bis(trimethylsilyl)-S-phenyl-sulfinimidamidetetrahydrofuran) (6)

Yield $2.34 \mathrm{~g}(64 \%){ }^{1} \mathrm{H}$ NMR: $\delta=0.21\left(\mathrm{~s}, \mathrm{SiMe}_{3}\right) ; 1.46\left(\mathrm{t}, \mathrm{O}\left(\mathrm{CH}_{2}\right)_{2}\left(\mathrm{CH}_{2}\right)_{2}\right) ; 3.51$

$\left(\mathrm{t}, \mathrm{O}\left(\mathrm{CH}_{2}\right)_{2}\left(\mathrm{CH}_{2}\right)_{2}\right) ; 7.19-7.80\left(\mathrm{~m}_{1} \mathrm{C}_{6} \mathrm{H}_{5}\right) .{ }^{13} \mathrm{C} \mathrm{NMR:} \delta=3.43\left(\mathrm{Si}\left(\mathrm{CH}_{3}\right)_{3}\right) ; 25.93$,

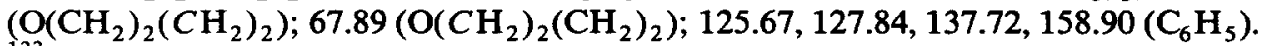
${ }^{133} \mathrm{Cs}-\mathrm{NMR}: \delta=156.12$.

Bis(lithium-N,N'-bis(trimethylsilyl)-S-tert-butylsulfinimidamide) (7)

Yield $2.30 \mathrm{~g}(85 \%) .{ }^{1} \mathrm{H}$ NMR: $\delta$ NMR: $\delta=0.26$ (s), 0.27 (s) $\left(\mathrm{SiMe}_{3}\right) ; 1.01$ (s, $\left.\mathrm{S}^{\mathrm{t}} \mathrm{C}_{4} \mathrm{H}_{9}\right) .{ }^{7} \mathrm{Li} \mathrm{NMR:} \delta=1.59 .{ }^{13} \mathrm{C} \mathrm{NMR}: \delta=2.60,2.97\left(\mathrm{Si}\left(\mathrm{CH}_{3}\right)_{3}\right) ; 22.78,23.25$ $\left(\mathrm{S}-\mathrm{C}\left(\mathrm{CH}_{3}\right)_{3}\right)$; ca. $36\left(\mathrm{~m}, \mathrm{~S}-\mathrm{C}\left(\mathrm{CH}_{3}\right)_{3}\right.$. 
Bis(lithium-N-trimethylsilyl-N'-tert-butyl-S-tert-butylsulfinimidamide) (8)

Yield $2.26 \mathrm{~g}(89 \%)$. ${ }^{1} \mathrm{H}$ NMR: $\delta=0.23$ (s, $\left.\mathrm{SiMe}_{3}\right) ; 1.06$ (s), 1.07 (s) $\left(\mathrm{S}^{\mathrm{t}} \mathrm{C}_{4} \mathrm{H}_{9}\right.$ ); 1.24 (s), 1.25 (s) $\left(\mathrm{N}^{\mathrm{t}} \mathrm{C}_{4} \mathrm{H}_{9}\right) .{ }^{7} \mathrm{Li} \mathrm{NMR:} \delta=1.87 .{ }^{13} \mathrm{C} \mathrm{NMR}: \delta=3.29\left(\mathrm{Si}\left(\mathrm{CH}_{3}\right)_{3}\right)$; $24.48,24.56\left(\mathrm{~S}-\mathrm{C}\left(\mathrm{CH}_{3}\right)_{3}\right) ; 33.50,33.81\left(\mathrm{~N}-\mathrm{C}\left(\mathrm{CH}_{3}\right)_{3}\right) ; 34.98\left(\mathrm{~S}-\mathrm{C}\left(\mathrm{CH}_{3}\right)_{3}\right) ; 54.14$ $\left.\mathrm{N}-\mathrm{C}\left(\mathrm{CH}_{3}\right)_{3}\right)$. The appearance of two signals for the tert-butyl groups reflect the disorder found in the crystal structure.

\section{$X-R a y$ crystal structure determinations of $2 a, 3-8$}

The structures of 2a, 3-8 were measured on a Stoe-Siemens-AED four-circle diffractometer with graphite-monochromated $M o-K_{\alpha}$ radiation $(\lambda=71.069 \mathrm{pm})$ at $-120^{\circ} \mathrm{C}$ for $2 \mathrm{a}, 3-5$, and 8 ; for $6\left(-60^{\circ} \mathrm{C}\right)$ and $7\left(-80^{\circ} \mathrm{C}\right)$ data had to be collected at higher temperatures because of phase transitions at lower temperatures. The structures of $2 a, 3,4,7$ and 8 were solved by direct methods [19] and those of 5 and 6 by Patterson methods. All structures were refined by full-matrix least-squares, with all non-hydrogen atoms anisotropic. The hydrogen atoms were found by difference Fourier synthesis and refined with a riding model. Chemically equivalent hydrogen atoms were refined with the same isotropic displacement parameters. For 5 and 6, a semi-empirical absorption correction was applied. Disorder involving tert-butyl and trimethylsilyl groups in $\mathbf{3}$ and $\mathbf{8}$ was treated with a refinement of the site occupation factors of the silicon and carbon atoms at the relevant positions. In 5 a trimethylsilyl group, and in 3 and 5 a THF-molecule, were disordered. In both cases, the site occupation of the disordered atoms was refined. In all cases a weighting scheme with $w^{-1}=\sigma^{2}(F)+g F^{2}$ was used. The factor $g$ for each structure can be found in Table 1. Crystallographic data are found in Table 1, and fractional coordinates and equivalent isotropic displacement parameters in Tables $3-7,9$ and 10 .

\section{Acknowledgements}

This work was supported by the Fonds der Chemischen Industrie.

\section{References and notes}

1 U. Wannagat and H. Kuckertz, Angew. Chem., 74 (1962) 117.

2 O.J. Scherer and R. Schmitt, J. Organomet. Chem., 16 (1969) P11.

3 J. Kuyper and K. Vrieze, J. Chem. Soc., Chem. Commun., (1976) 64.

4 J. Kuyper, P.C. Keijzer and K. Vrieze, J. Organomet. Chem., 116 (1976) 1.

5 O.J. Scherer and R. Wies, Z. Naturforsch. B, 25 (1970) 1486.

6 D. Hänssgen and R. Steffens, J. Organomet. Chem., 236 (1982) 53.

7 D. Hanssgen and R. Steffens, Z. Naturforsch. B, 40 (1985) 919.

8 D. Hänssgen and R. Plum, Chem. Ber., 120 (1987) 1063.

9 D. Stalke, F. Pauer, F.T. Edelmann, F. Knösel and W. Bauer, to be published.

10 M. Veith and J. Böhnlein, Chem. Ber., 122 (1989) 603.

11 M. Veith, J. Böhnlein and V. Huch, Chem. Ber., 122 (1989) 841.

12 U. Pieper, D. Stalke, S. Vollbrecht and U. Klingebiel, Chem. Ber., 123 (1990) 1039.

13 D. Stalke, N. Keweloh, U. Klingebiel, M. Noltemeyer and G.M. Sheldrick, Z. Naturforsch. B, 42 (1987) 1237.

14 D. Stalke, U. Klingebiel and G.M. Sheldrick, J. Organomet. Chem., 344 (1988) 37.

15 K. Vrieze and G. van Koten, Recl. Trav. Chim. Pays-Bas, 99 (5) (1980) 145.

16 C. Schade and P.v.R. Schleyer, Adv. Organomet. Chem., 27 (1987) 169.

17 G. Rabe, H.W. Roesky, D. Stalke, F. Paiuer and G.M. Sheldrick, J. Organomet. Chem., 403 (1991) 11. 
18 In contrast to the $\left[\mathrm{Ph}_{3} \mathrm{C}\right]^{-} \mathrm{Li}^{+}$- and $\left[\mathrm{Ph}_{3} \mathrm{C}\right]^{-} \mathrm{Na}^{+}$-derivatives, the alkali metal in the structure of $\left[\mathrm{Ph}_{3} \mathrm{C}\right]^{-} \mathrm{K}^{+}$determined by us, in collaboration with D. Hoffmann and P.v.R. Schleyer, is situated almost exactly above the centre of a phenyl ring.

19 G.M. Sheldrick, Acta Crystallogr., Sect. A, 46 (1990) 467.

20 Further details of the crystal structure analyses can be obtained from the Fachinformationszentrum Karlsruhe, Gesellschaft für wissenschaftlich-technische Information mbH, W-7514 EggensteinLeopoldshafen 2, Germany by quoting the deposit number CSD-55091, the authors, and the publication. 